\title{
PENGARUH PEMBERIAN COCONUT OIL TERHADAP KEJADIAN RUAM POPOK PADA BAYI
}

\author{
Ernauli Meliyana ${ }^{1}$, Nia Hikmalia ${ }^{2}$ \\ ${ }^{1}$ Sekolah Tinggi Ilmu Kesehatan Medistra Indonesia \\ ${ }^{2}$ Sekolah Tinggi Ilmu Kesehatan Medistra Indonesia \\ Email : cellohtst@yahoo.com ${ }^{1}$ niahikmalia6@gmail.com ${ }^{2}$
}

\begin{abstract}
ABSTRAK
Kondisi kulit pada bayi yang relatif lebih tipis menyebabkan bayi lebih rentan terhadap infeksi, iritasi dan alergi. Salah satu masalah kulit yang masih sering terjadi pada bayi dan anak adalah diaper dermatitis/diaper rash atau sering disebut juga dengan ruam popok. Penanganan ruam popok pada bayi salah satunya dengan pemberian Coconut oil, merupakan pelembab alamiah dan mengandung asam lemak jenuh rantai sedang yang mudah masuk ke lapisan kulit dan mempertahankan kelenturan serta kekenyalan kulit. Penelitian ini bertujuan untuk mengetahui pengaruh pemberian coconut oil terhadap kejadian ruam popok pada bayi di Posyandu Flamboyan Wilayah Puskesmas Karangjaya Pedes 2017. Adapun metode penelitian ini menggunakan rancangan preeksperimental design, dengan metode penelitian one group pretest posttest design. Jumlah sampel sebanyak 16 responden. Sampel yang digunakan yaitu bayi yang mengalami ruam popok di Posyandu Flamboyan Wilayah Puskesmas Karangjaya Pedes 2017. Hasil analisis Paired T-test menunjukan $p$ value $0,000<\alpha 0,05$, artinya ada pengaruh yang signifikan antara pemberian coconut oil terhadap kejadian ruam popok pada bayi di Posyandu Flamboyan Wilayah Puskesmas Karangjaya Pedes 2017. Dari hasil tersebut dapat disimpulkan bahwa setelah dilakukannya pemberian coconut oil pada bayi yang mengalami kejadian ruam popok mengalami penurunan.
\end{abstract}

Kata kunci: Coconut oil, Ruam popok, Bayi

\section{THE EFFECT OF COCONUT OIL ON THE OCCURRENCE OF DIAPER RASH IN INFANTS}

\begin{abstract}
Skin conditions in relatively thin infants make babies more susceptible to infections, irritants and allergies. One of the skin problems that are still common in infants and children is diaper dermatitis / diaper rash or often called a diaper ras. Handling of diaper rash in infants one of them with the provision of coconut oil, is a natural moisturizer and contains medium chain saturated fatty acids that easily enter the skin layer and maintain flexibility and elasticity of the skin. The aim of this research is to find out whether there is any effect of coconut oil on the occurrence of diaper rash in infants at Posyandu Flamboyan Area Health Center Karangjaya Pedes 2017. While the method of this research was used Using preeksperimental design, with one group pretest posttest design research method. The number of sampel are 16 respondens. The sampel is infants who have diaper rash at Posyandu Flamboyan Area Health Center Karangjaya Pedes 2017. The result of Paired T-test showed $p$ value $0,000<\alpha$ 0,05, which means there is a significant effect The effect of Coconut oil on the occurrence of diaper rash in infants at Posyandu Flamboyan Area Health Center Karangjaya Pedes 2017. From these results it can be concluded that after doing the provision of coconut oil in infants who experience the includence of diaper rash has decreased.
\end{abstract}

Keywords: Coconut oil, Diaper Rash, Infant 


\section{PENDAHULUAN}

Bayi merupakan makhluk hidup yang diciptakan oleh Tuhan dengan individu yang unik. Setiap orang tua pasti selalu memberikan perawatan yang terbaik, karena bagi setiap orang tua sehat itu sangat penting. Dengan demikian memiliki bayi yang sehat merupakan dambaan setiap orang tua, karena bayi sangat sensitif terhadap apa pun yang ada dilingkungan sekitarnya. Masa neonatus sampai dengan pasca-neonatus juga merupakan usia yang rapuh baik untuk fisik, penyakit maupun kecelakaan. Karenanya pada kelahiran pertama bayi baru beradaptasi terhadap semua kondisi lingkungan di sekitarnya, sehingga belum terbiasa dengan keadaan yang menyerang kondisi tubuhnya, terutama masalah kulit, kondisi kulit bayi memiliki kepekaan yang lebih dibandingkan dengan kulit orang dewasa, oleh sebab itu bayi lebih mudah kehilangan panas melalui permukaan kulit. Kulit bayi mengandung lebih banyak air dibanding kulit orang dewasa, dan epidermis berikatan longgar dengan dermis. Hal tersebut berarti bahwa gesekan mudah menyebabkan pemisahan lapisan tersebut, yang mengkibatkan pembentukan lepuh atau kerusakan kulit. Kulit bayi juga kurang pigmentasi dibandingkan dengan kulit orang dewasa (pada semua ras), yang membuat bayi berisiko lebih tinggi terhadap kerusakan kulit akibat radiasi ultraviolet. ${ }^{1}$

Kondisi kulit pada bayi yang relatif lebih tipis menyebabkan bayi lebih rentan terhadap infeksi, iritasi dan alergi. Salah satu masalah kulit yang masih sering terjadi pada bayi dan anak adalah diaper dermatitis/diaper rash atau sering disebut juga dengan ruam popok. Ruam popok adalah radang /infeksi kulit di sekitar area popok seperti paha dan pantat bayi, yang umumnya disebabkan terpaparnya kulit bayi pada zat amonia yang terkandung dalam urin atau feses bayi dalam jangka waktu lama. $^{2}$

Apabila diaper rash tidak segera ditangani atau diobati maka akan menyebabkan ulkus punch-out atau erosi dengan tepi meninggi (Jacquet erosive diaper dermatitis), papul dan nodul pseudoverucous dan plak dan nodul violaeous (granuloma gluteale infantum). ${ }^{3}$ Pengobatan ruam popok ada 2 cara antara lain secara farmakologis dan nonfarmakologis. Pemberian terapi non farmokologis salah satunya yaitu dengan menggunakan bahan olahan yang alami. Salah satu bahan olahan alami yang dapat dipertimbangkan sebagai terapi topical alternatif yang dapat digunakan untuk perawatan kulit pada bayi yang mengalami ruam popok yaitu coconut oil. Coconut oil adalah minyak kelapa murni yang hanya bisa dibuat dengan bahan kelapa segar nonkopra, pengolahan nya pun tidak menggunakan bahan kimia dan tidak menggunakan pemanasan yang tinggi serta tidak dilakukan pemurnian lebih lanjut, karena minyak kelapa murni sangat alami dan sangat stabil jika digunakan dalam beberapa tahun kedepan. ${ }^{4}$

Coconut oil juga mengandung pelembab alamiah dan mengandung asam lemak jenuh rantai sedang yang mudah masuk ke lapisan kulit dalam dan mempertahankan kelenturan serta kekenyalan kulit. Asam laurat dan asam kaprat yang terkandung di dalam coconut oil mampu membunuh virus. Di dalam tubuh, asam laurat diubah menjadi monokaprin, senyawa ini termasuk senyawa monogliserida yang bersifat sebagai antivirus, antibakteri, antibiotik dan antiprotozo. 5

Minyak kelapa adalah solusi yang aman untuk mencegah kekeringan dan pengelupasan kulit, manfaat minyak kelapa pada kulit adalah sebanding dengan minyak 
mineral, tidak memiliki efek samping yang merugikan pada kulit. Hal ini minyak kelapa juga membantu dalam mengobati berbagai masalah kulit termasuk psoriasis, dermatitis, eksim dan infeksi kulit lainnya. ${ }^{6}$ Berdasarkan data yang dikeluarkan oleh Badan Kesehatan Dunia (WHO) prevalensi iritasi kulit (ruam popok) pada bayi cukup tinggi $25 \%$ bayi yang lahir di dunia kebanyakan menderita iritasi kulit (ruam popok) akibat penggunaan popok. Angka terbanyak ditemukan pada usia 6-12 bulan. ${ }^{7}$

Prevalensi dermatitis popok dalam populasi umum adalah antara $7 \%$ dan 35 $\%$, prevalensi bayi dirawat di rumah sakit dan anak-anak berkisar dari $17 \%$ menjadi 43\%, di Amerika Serikat sekitar 1 juta kunjungan perawatan kesehatan untuk dermatitis popok terjadi per tahun, dengan $25 \%$ dari anak-anak berisiko di diagnosis dengan dermatitis. Dermatitis popok ditemukan paling umum di antara anak-anak dibawah usia 2 tahun, dengan mayoritas kasus ditemukan pada anak-anak di bawah usia 1 tahun. ${ }^{6}$ Insiden ruam popok di Indonesia mencapai 7-35\%, yang menimpa bayi laki-laki dan perempuan berusia dibawah tiga tahun. ${ }^{8}$ Ahli Menteri Kesehatan Bidang Peningkatan Kapasitas dan Desentralisasi, dr. Krisnajaya, MS memperkirakan jumlah anak balita (bawah lima tahun) Indonesia mencapai $10 \%$ dari populasi penduduk. Jika jumlah penduduknya 220-240 juta jiwa, maka setidaknya ada 22 juta balita di Indonesia mengalami ruam popok. ${ }^{7}$

Berdasarkan hasil studi pendahuluan yang dilakukan peneliti pada tanggal 3 Maret 2017, di wilayah Puskesmas Karangjaya Pedes diketahui bahwa prevalensi dermatitis popok pada tahun 2016 terdapat 11 bayi dari 18 bayi sementara pada tahun 2017 ini hampir 19 bayi dari 23 bayi yang mengalami kemerahan di daerah simpisis pubis, gluteal, alat genital, perianal, dan lipatan paha. Selain itu, setelah di teliti faktor penyebab terjadinya ruam popok pada bayi-bayi tersebut adalah pemakaian popok sekali pakai serta frekuensi BAB dan BAK yang terlalu sering.

Hasil wawancara juga diketahui bahwa beberapa orang tua bayi menggunakan bedak untuk mengatasi ruam popok pada bayinya. Orang tua yang masih memakaikan bedak belum mengetahui bahwa bedak dapat memperparah ruam popok karena gumpalan bedak bisa bercampur dengan keringat dan menjadi lebih gatal menyumbat muatra saluran kelenjar keringat dan dapat menjadi media yang baik untuk pertumbuhan bakteri yang akan menyebabkan infeksi pada kulit. Pemakaian bedak cenderung membuat kulit bayi menjadi lebih kering, juga tidak dianjurkan karena serbuk bedak dapat terhirup oleh paru-paru bayi dan menimbulkan keluhan pada bayi yang mempunyai hipersensitivitas atau alergi pada saluran napasnya. Daerah kemaluan tidak boleh dibedaki karena bedak bisa menggumpal dan menutupi muara saluran kemih, sehingga bayi bisa mengalami kesulitan kencing. ${ }^{8}$

Selain itu juga banyak orang tua yang menggunakan coconut oil untuk mengatasi ruam popok atau diaper reash. Tidak hanya untuk mengatasi ruam popok saja ternyata banyak dari orang tua juga menggunakannya untuk iritasi kulit lainnya seperti bintik merah oleh nyamuk, bentol, luka, serta membersihkan kotoran di kulit kepala dan yang lainnya. Fenomena tersebut membuat peneliti tertarik untuk melakukan penelitian tentang pengaruh pemberian coconut oil terhadap kejadian ruam popok pada bayi di Posyandu Flamboyan Wilayah Puskesmas Karangjaya Pedes.

Adapun tujuan dari penelitian ini yaitu untuk mengetahui pengaruh pemberian coconut oil terhadap kejadian ruam popok 
pada bayi di Posyandu Flamboyan Wilayah Puskesmas Karangjaya Pedes 2017.

\section{METODE}

Penelitian ini menggunakan jenis penelitian kuantitatif dengan desain penelitian Quasi Eksperiman rancangan preeksperimental design, dengan metode penelitian one group pretest posttest design yaitu dilakukan dengan cara tidak ada kelompok pembanding (Kontrol), tetapi paling tidak sudah dilakukan observasi pertama (pretest) yang memungkinkan menguji perubahan-perubahan yang terjadi setelah adanya eksperimen. ${ }^{9}$ Populasi dalam penelitian ini adalah seluruh bayi yang mengalami ruam popok di Posyandu Flamboyan Wilayah Puskesmas Karangjaya Pedes sebanyak 19 bayi yang mengalami ruam popok. Sampel dalam penelitian ini adalah 16 bayi yang mengalami ruam popok di Posyandu Flamboyan Wilayah Puskesmas Karangjaya Pedes yang sesuai dengan kriteria inklusi yaitu bayi yang mengalami ruam popok derajat I dan II di Posyandu Flamboyan Wilayah Puskesmas Karangjaya Pedes, bayi yang memakai popok/pempers, orang tua bayi yang bersedia menjadi responden dalam penelitian, sedangkan untuk kriteria eksklusi pada penelitian ini yaitu bayi yang tidak berada di Posyandu Flamboyan Wilayah Puskesmas Karangjaya Pedes, bayi yang mengalami ruam popok derajat III, bayi yang sedang menjalankan pengobatan secara farmakologis.

Sampel dalam penelitian ini dipilih dengan teknik non-probability sampling jenis purposive sampling, yaitu suatu metode pemilihan sampel yang dilakukan berdasarkan pada suatu pertimbangan yang dibuat oleh peneliti sendiri. ${ }^{9}$ Pada penelitian ini untuk mendapatkan informasi sesuai yang dibutuhkan, peneliti menggunakan instrument dalam penelitian ini adalah lembar observasi skor derajat ruam popok dan SOP. Untuk mendapatkan hasil derajat ruam popok peneliti menggunakan lembar observasi skor derajat ruam popok. Lembar observasi skor derajat ruam popok adalah suatu daftar untuk pengecekan perubahanperubahan kondisi ruam popok yang terjadi selama penelitian, yang berisi nama responden, usia, hari/tanggal, pretest yaitu penjelasan kondisi ruam popok sebelum dilakukan intervensi, post test yaitu penjelasan kondisi ruam popok setelah dilakukan intervensi dan hasil derajat yaitu penilaian/coding dari hasil intervensi. Sedangkan untuk pemberian coconut oil pada bayi peneliti menggunakan Standard Operasional Prosedur.(SOP)

Tempat penelitian yang digunakan oleh peneliti yaitu di Posyandu Flamboyan Wilayah Puskesmas Karangjaya Pedes tepatnya di Kabupaten Karawang pada tanggal 19 Mei sampai dengan 22 Mei 2017. Jenis data yang digunakan dalam penelitian ini adalah data primer dan data sekunder. Data primer dalam penelitian ini diperoleh dari pengkajian keadaan ruam popok pada bayi. Data sekunder dalam penelitian ini diperoleh dari Posyandu Flamboyan Wilayah Puskesmas Karangjaya berupa nama, usia, jenis kelamin, jumlah bayi, jumlah bayi yang mengalami ruam popok. Pengumpulan data dilakukan secara langsung terhadap responden yang sebelumnya sudah mendapatkan perizinan dari Posyandu Flamboyan Wilayah Puskesmas Karangjaya Pedes. Selanjutnya peneliti melakukan tahap pendekatan dengan responden dan orang tua responden untuk menjelaskan maksud dan tujuan peneliti. Peneliti menyerahkan surat persetujuan untuk menjadi responden atau inform consent bahwa orang tua responden menyetujui bayinya dijadikan responden peneliti.

Sebelum intervensi diberikan selanjutnya pasien dikaji keadaan derajat 
ruam popok nya terlebih dahulu, setelah itu diberikan intervensi pemberian coconut oil pada pagi dan sore selama 4 hari. Pagi hari peneliti datang untuk melakukan pengukuran pada kejadian ruam popok dan menanyakan kondisi ruam popok bayi nya kepada orang tua selama diberikan coconut oil. Setelah data terkumpul dalam 4 hari selanjutnya data diolah dan dianalisis. Analisa univariat dalam penelitian ini adalah untuk dapat mengidentifikasi derajat ruam popok sebelum dan sesudah dilakukan intervensi pada bayi di Posyandu Wilayang Puskesmas Karangjaya Pedes. Analisa Bivariat dalam penelitian ini menggunakan analisis komparasi dengan uji paired t-test. Adapun analisa data dianalisa menggunakan Software Statistik berbasis komputerisasi. Semua data dianalisis pada tingkat kemaknaan (confidence interval) 95\% $(\alpha=0,05)$. Etika penelitian bertujuan untuk menjaga kerahasiaan identitas responden akan kemungkinan terjadi ancaman terhadap responden. Masalah etika ini ditekankan pada informed consent, Anonimaty, Confidentiality, dan Justice.

\section{HASIL}

\section{Analisa Univariat}

a) Rata-rata Kejadian Ruam Popok Pada Bayi di Posyandu Flamboyan Wilayah Puskesmas Karangjaya Pedes

\section{Tabel 1}

Rata-rata Kejadian ruam popok bayi di Posyandu Flamboyan Wilayah Puskesmas Karangjaya Pedes

\begin{tabular}{lccc}
\hline \multicolumn{1}{c}{ Derajat } & F & $\%$ & Mean \\
\cline { 1 - 3 } Tidak ada ruam & - & - & \\
\cline { 1 - 3 } Kemerahan & 8 & 50 & \\
\cline { 1 - 3 } $\begin{array}{l}\text { Papul yang berisi } \\
\text { cairan }\end{array}$ & 8 & 50 & \\
\hline
\end{tabular}

\begin{tabular}{llll}
\hline Total & 16 & 100 & - \\
\hline
\end{tabular}

Tabel 1 menunjukan bahwa kejadian ruam popok pada bayi di Posyandu Flamboyan Wilayah Puskesmas Karangjaya Pedes adalah sebanyak 16 orang bayi yang mengalami kejadian ruam popok diantaran 8 orang bayi yang mengalami derajat 1 dar orang bayi yang mengalami derajat 2 .

b) Rata-rata kondisi derajat ruam popok sebelum dan sesudah diberikan Coconut oil pada bayi di Posyandu Flamboyan Wilayah Puskesmas Karangjaya Pedes

Tabel 2

Rata-rata kondisi derajat ruam popok bayi sebelum diberikan Coconut oil di Posyandu Flamboyan Wilayah Puskesmas Karangjaya Pedes

\begin{tabular}{|c|c|c|c|}
\hline Derajat & $\mathrm{F}$ & $\%$ & Mean \\
\hline 0 (Tidak ada ruam) & - & - & \multirow{3}{*}{1,50} \\
\hline 1 (Kemerahan) & 8 & 50 & \\
\hline $\begin{array}{l}2 \text { (Papul yang berisi } \\
\text { cairan) }\end{array}$ & 8 & 50 & \\
\hline Total & 16 & 100 & - \\
\hline
\end{tabular}

Tabel 2 menunjukan bahwa karakteristik derajat ruam popok sebelum dilakukan pemberian Coconut oil dari 16 (100\%) responden, terdapat 8 bayi yang mengalami ruam popok derajat 1 dengan besar persentase $50 \%$ dan terdapat 8 bayi yang mengalami ruam popok derajat 2 dengan persentase $50 \%$, dengan nilai ratarata 1,50 . 
Tabel 3

Rata-rata kondisi derajat ruam popok bayi sesudah diberikan coconut oil di Posyandu

Flamboyan Wilayah Puskesmas

Karangjaya

Pedes

\begin{tabular}{lccc}
\hline \multicolumn{1}{c}{ Derajat } & F & $\%$ & Mean \\
\cline { 1 - 3 } Tidak ada ruam & 7 & 43,8 & \\
\cline { 1 - 3 } Kemerahan & 7 & 43,8 & 0,69 \\
$\begin{array}{llll}\text { Papul yang } \\
\text { berisi cairan }\end{array}$ & 2 & 12,5 & \\
\cline { 1 - 3 } Total & $\mathbf{1 6}$ & $\mathbf{1 0 0}$ & - \\
\hline
\end{tabular}

bayi yang mengalami ruam popok derajat 1 yakni 6 bayi yang mengalami ruam popok derajat 2 menjadi ruam popok derajat 1 , dan 1 bayi yang mengalami derajat 1 setelah 4 hari pemberian coconut oil tidak mengalami perubahan masih mengalami derajat 1 , dengan persentase $43,8 \%$, dan terdapat 2 bayi yang mengalami ruam popok derajat 2 diantaranya yaitu 1 bayi yang mengalami
Tabel 3 menunjukan bahwa karakteristik derajat ruam popok sesudah dilakukan pemberian Coconut oil dari 16 (100\%) responden, terdapat 7 bayi yang mengalami ruam popok derajat 0 (Tidak ada ruam) diantaranya yaitu 6 bayi yang mengalami ruam popok derajat 1 mer ${ }^{\cdot} \cdot{ }_{5}$ ruam popok derajat 0,1 bayi \& mengalami ruam popok derajat 2 menjauı ruam popok derajat 0,dengan besar persentase $43,8 \%$, terdapat 7

ruam popok derajat 2 masih tetap mengalami ruam popok derajat 2 dimana tidak mengalami perubahan, dan bayi yang mengalami ruam popok derajat 1 setelah 4 hari dilakukan pemberian coconut oil tidak mengalami perubahan yaitu mengalami peningkatan/memperparah ruam popok menjadi derajat 2 dengan persentase $15 \%$, dengan nilai rata-rata 0,69 .

\section{2, Analisa Bivariat}

\section{Tabel 4}

Perbedaan Pemberian Coconut Oil Terhadap Kejadian Ruam Popok Pada Bayi di Posyandu Flamboyan Wilayah Puskesmas Karangjaya Pedes 2017

\begin{tabular}{cccccccc}
\hline Variabel & $\begin{array}{c}\text { Penguku } \\
\text { ran }\end{array}$ & F & Mean & $\begin{array}{c}\text { St. } \\
\text { Deviasi } \\
\text { Ruam Popok }\end{array}$ & $\begin{array}{c}\boldsymbol{P} \\
\text { Value }\end{array}$ & $\begin{array}{c}\text { T } \\
\text { Hitung }\end{array}$ & $\begin{array}{c}\text { T Tabel } \\
(\mathbf{d f}=\mathbf{1 4})\end{array}$ \\
& Sebelum & 16 & 1,50 & 0,516 & & & \\
& Sesudah & 16 & 0,69 & 0,704 & & & \\
\hline
\end{tabular}

Tabel 4 menunjukan hasil uji perbedaan dua kali pengukuran (Paired T-test) yang menunjukan bahwa sebelum dilakukan intervensi pemberian Coconut oil rata-rata kondisi derajat ruam popok yaitu 8 orang yang mengalami derajat 1 dan 8 orang yang mengalami derajat 2 dengan persentase masing-masing $50 \%$, dengan besar mean
1,50 (St. Deviasi: 0,516) dan setelah diberikan intervensi pemberian Coconut oil rata-rata kondisi derajat ruam popok pada bayi mengalami penurunan yaitu 7 orang bayi yang mengalami derajat 0 (tidak ada ruam), 7 orang bayi yang mengalami derajat 1 dan 2 orang bayi yang mengalami derajat 2 dengan besar mean 0,69 (St. Deviasi: 0,704), 
hasil analisis Paired T-test menunjukan $P$ Value $0,000<\alpha 0,05 ; \mathrm{T}$ hitung $(\mathrm{df}=14)$ 4,961 > T Tabel 2,131 yang menyatakan bahwa pada tingkat kepercayaan $95 \%$ ada perbedaan kejadian derajat ruam popok pada bayi sebelum dan sesudah diberikan intervensi pemberian Coconut oil.

\section{PEMBAHASAN}

\section{Analisa Univariat}

a) Mengetahui kejadian ruam popok pada bayi di Posyandu Flamboyan Wilayah Puskesmas Karangjaya Pedes 2017.

Berdasarkan hasil penelitian yang dilakukan oleh peneliti menunjukan bahwa bayi yang mengalami kejadian ruam popok di Posyandu Flamboyan Wilayah Puskesmas Karangjaya Pedes terdapat 8 bayi yang mengalami ruam popok derajat 1 terdiri dari 2 laki-laki, 6 perempuan, hal ini dikarenakan kebiasaan orang tua yang menunda membersihkan kulit yang terkena urin/feses dalam jangka waktu lama membuat bakteri menumpuk disekitar area popok, serta setiap hari bayinya selalu dipakaikan popok sekali pakai/pempers karena malas menggantikan popok bayinya setiap kali BAB/BAK sehingga pemakaian popok yang terlalu sering dan lama dapat memicu terjadinya ruam popok disebabkan oleh kulit yang yang terlalu lembab dan 8 bayi yang mengalami ruam popok derajat 2 terdiri dari 6 laki-laki, 2 perempuan.

Setelah diwawancarai hal ini disebabkan bahwa orang tua bayi masih belum paham mengenai perawatan bayi yang baik dan benar, orang tua bayi juga mengatakan sudah pernah mendapatkan penyuluhan oleh pihak puskesmas tentang perawatan bayi yang baik dan benar akan tetapi kadang suka lupa-lupa ingat apalagi saat dalam keadaan bayi nya terluka/sakit sehingga panik dan bingung harus melakukan apa, serta saat bayinya BAB/BAK kebiasaan orang tuanya hanya di lap dengan kain lalu langsung menggantikan popok nya saja tidak dibersihkan dahulu denga menggunakan air bersih dan juga saat setelah mendapatkan penyuluhan oleh pihak puskesmas tentang perawatan bayi yang baik dan benar akan tetapi kadang suka lupa-lupa ingat apalagi saat dalam keadaan bayinya terluka/sakit sehingga panik dan bingung harus melakukan apa, serta saat bayinya BAB/BAK kebiasaan orang tuanya hanya di lap dengan kain lalu langsung menggantikan popok nya saja tidak dibersihkan dahulu dengan menggunakan air bersih dan juga saat setelah dibersihkan langsung diberikan bedak tidak dianginkan terlebih dahulu sehingga bedak menggumpal dan trcampur dengan urin/feses menimbulkan penumpukan bakteri, dan yang lebih parah ada orang tua yng memberikan povidone iodine untuk mengobati ruam popok setelah diketahui bahwa orang tua bayi tersebut tidak pernah mengikuti kegiatan-kegiatan penyuluhan dari pihak tim kesehatan manapun dan melahirkan di dukun beranak.

Terdapat 3 klasifikasi ruam popok diantaranya yaitu derajat I terjadi kemerahan, derajat II (Papul) yang berisi cairan, derajat III (Pus). ${ }^{3}$ Ruam popok umumnya disebabkan terpaparnya kulit bayi pada zat amonia yang terkandung dalam urin atau feses bayi dalam jangka waktu lama. ${ }^{2}$ Apabila diaper rash tidak segera ditangani atau diobati maka akan menyebabkan ulkus punch-out atau erosi dengan tepi meninggi. ${ }^{3}$ 
b) Mengidentifikasi kondisi ruam popok sesudah dilakukan pemberian coconut oil pada bayi di Posyandu Flamboyan Wilayah Puskesmas Karangjaya Pedes 2017.

Berdasarkan hasil analisa univariat yang dilakukan oleh peneliti menunjukan bahwa kondisi ruam popok bayi sesudah dilakukan pemberian Coconut oil dari 16 (100\%) responden, terdapat 13 bayi yang mengalami perubahan, 2 bayi yang menetap/tidak mengalami perubahan, 1 bayi yang mengalami peningkatan. Sebelum dilakukan pemberian coconut oil rata-rata kondisi derajat ruam popok pada bayi 1,50 diantaranya terdapat 8 bayi yang mengalami ruam popok derajat 1 dan terdapat 8 bayi yang mengalami ruam popok derajat 2 tetapi setelah dilakukan pemberian coconut oil menunjukan menjadi 0,69 diantaranya 6 bayi yang mengalami ruam popok derajat 2 menjadi ruam popok derajat 1,6 bayi yang mengalami ruam popok derajat 1 menjadi ruam popok derajat 0,1 bayi yang mengalami ruam popok derajat 2 menjadi ruam popok derajat 0 , terdapat 2 bayi yang dibersihkan langsung diberikan bedak tidak di anginkan terlebih dahulu sehingga bedak menggumpal dan tercampur dengan urin/feses menimbulkan penumpukan bakteri, dan yang lebih parah ada orang tua yang memberikan povidone iodine untuk mengobati ruam popok setelah diketahui bahwa orang tua bayi tersebut tidak pernah mengikuti kegiatan-kegiatan penyuluhan dari pihak tim kesehatan manapun dan melahirkan di dukun beranak. iodine untuk mengobati ruam popok setelah diketahui bahwa orang tua bayi tersebut tidak pernah mengikuti kegiatan-kegiatan penyuluhan dari pihak tim kesehatan manapun dan melahirkan di dukun beranak. Ruam popok dapat terjadi disebabkan karena kulit terlalu lembab, terjadi luka atau gesekan, kulit terlalu lama terkena urin, feses atau keduanya, infeksi jamur, reaksi alergi terhadap bahan popok, gangguan pada kelenjar keringat di area yang tertutup popok, dan reaksi kontak terhadap karet, plastik, detergen. $^{3}$

c) Mengidentifikasi kondisi ruam popok sebelum dilakukan pemberian coconut oil pada bayi di Posyandu Flamboyan Wilayah Puskesmas Karangjaya Pedes 2017.

Berdasarkan hasil penelitian yang dilakukan oleh peneliti menunjukan bahwa kondisi ruam popok bayi sebelum dilakukan pemberian Coconut oil dari $16(100 \%)$ responden, terdapat 8 bayi yang mengalami ruam popok derajat 1, hal ini dikarenakan kebiasaan orang tua yang menunda membersihkan kulit yang terkena urin/feses saat bayinya BAB/BAK sehingga kulit bayi basah terkena urin/feses dalam jangka waktu lama membuat bakteri menumpuk disekitar area popok, serta setiap hari bayinya selalu dipakaikan popok sekali pakai/pempers karena malas menggantikan popok bayi nya setiap kali $\mathrm{BAB} / \mathrm{BAK}$ sehingga pemakaian popok yang terlalu sering dan lama dapat memicu terjadinya ruam popok disebabkan oleh kulit yang terlalu lembab.

Terdapat 8 bayi yang mengalami ruam popok derajat 2 hal ini disebabkan bahwa orang tua bayi masih belum paham mengenai perawatn byi yang baik dan benar, 
orang tua bayi juga mengatakan sudah tidak mengalami perubahan diantaranya bayi yang mengalami ruam popok derajat 1 serta bayi yang mengalami ruam popok derajat 2 setelah 4 hari pemberian coconut oil tidak mengalami perubahan masih mengalami ruam popok derajat 2 , dan terdapat 1 bayi yang mengalami peningkatan/memperparah ruam popok, diantaranya bayi yang mengalami ruam popok derajat 1 setelah 4 hari pemberian coconut oil ruam popok bayi mengalami peningkatan menjadi derajat 2.

Setelah di wawancarai mengenai perawatan ruam popok selama penelitian kepada orang tua bayi bahwa beliau masih ada yang menunda waktu penggantian popok saat bayi $\mathrm{BAK} / \mathrm{BAB}$, serta ada yang mengatakan bahwa saat malam hari masih dipakaikan popok sekali pakai/pempers alasan beliau bayi sering BAK sehingga orang tua bayi malas menggantikan popok sesering itu, sehubungan saat itu sedang musim hujan masih banyak orang tua bayi mengenakan popok sekali pakai/pempers terhadap bayi nya, dan lupa mengoleskan kembali minyak kelentik sesuai dengan yang diarahkan peneliti.

Pengukuran derajat ruam popok bertujuan untuk mengetahui apakah ada perbedaan antara hasil ukur derajat ruam popok sebelum dan sesudah dilakukan pemberian coconut oil. Hasil penelitian yang telah dilakukan menunjukan bahwa terjadi penurunan derajat ruam popok setelah dilakukan pemberian coconut oil pada bayi di Posyandu Flamboyan Wilayah Puskesmas Karangjaya Pedes. Hasil penelitian ini sesuai dengan penelitian pernah mendapatkan tapi suka lupa. tentang efektifitas minyak kelapa dan minyak zaitun terhadap pencegahan diaper dermatitis pada anak usia $3-24$ bulan, bahwa jumlah responden yang mengalami diaper dermatitis dengan terapi minyak kelapa lebih sedikit dibanding dengan responden yang mendapatkan terapi minyak zaitun, dari hasil penelitian didapatkan hasil dari 30 responden yang mendapatkan terapi minyak kelapa, sebanyak 27 responden (90\%) tidak terjadi diaper dermatitis dan 3 responden (10\%) mengalami kejadian diaper dermatitis. ${ }^{10}$

Hasil penelitian ini sesuai dengan teori yang menjelaskan bahwa minyak kelapa bermanfaat untuk kesehatan dan penyembuhan sebagai obat penyakit ringan hingga kategori berat, seperti mematikan jamur kulit dan fungus yang menyebabkan kandid kurap, kutu air, sariawan, diap dermatitis pada bayi, dan infek lainnya. ${ }^{10}$

\section{Analisa Bivariat}

Hasil uji normalitas yang dilakukan oleh peneliti menunjukan bahwa sebelum melakukan pemberian coconut oil pada 16 responden, kejadian ruam popok pada bayi didapatkan nilai $\mathrm{P}$ $(0,057)>$ nilai Alpha $(0,05)$ yang berarti data distribusi normal, sedangkan kejadian ruam popok pada bayi setelah di lakukan pemberian coconut oil didapatkan nilai $\mathrm{P}(0,184)>$ nilai Alpha $(0,05)$ yang berarti data distribusi normal. Berdasarkan hasil analisis tersebut, pada tingkat kemaknaan 95\% dinyatakan bahwa sebelum dan sesudah dilakukan pemberian coconut oil pada bayi dengan kejadian ruam popok di Posyandu Flamboyan Wilayah 
Puskesmas Karangjaya Pedes dinyatakan distribusi normal, dengan menggunakan Kolmogrov-smirnov test.

Berdasarkan hasil analisa bivariat dengan uji komparasi Paired sample ttest tentang kondisi derajat ruam popok sebelum dan sesudah dilakukan pemberian Coconut oil pada ruam popok bayi di Posyandu Flamboyan Wilayah Puskesmas Karangjaya Pedes dengan jumlah sampel sebanyak 16 responden $(n=16)$ pada kondisi derajat ruam popok di dapatkan data bahwa $\mathrm{T}$ hitung $\mathrm{df}=14$ $(4,961)>\mathrm{T}$ Tabel $(2,131)$ dan nilai $\mathrm{P}$ $(0,000)<$ nilai Alpha $(0,05)$ yang berarti ada perbedaan kondisi derajat ruam popok sebelum dan sesudah dilakukan pemberian Coconut oil, dimana rata-rata kondisi derajat ruam popok sesudah dilakukan pemberian Coconut oil lebih rendah $(m=0,69)$ daripada sebelum dilakukan pemberian Coconut oil $(m=1,50)$.

Hasil analisa komparasi di dapatkan hasil $\mathrm{T}$ hitung derajat ruam popok pada bayi $(4,961)>\mathrm{T}$ Tabel $(2,131)$ dan nilai P $(0,000)<$ nilai Alpha $(0,05)$. Sehingga dapat disimpulkan bahwa pada hasil uji hipotesis dinyatakan $\mathrm{H}_{0}$ ditolak artinya ada pengaruh pemberian Coconut oil terhadap kjadian ruam popok pada bayi di Posyandu Flamboyan Wilayah Puskesmas Karangjaya Pedes. Penlitian ini sejalan dengan penelitian tentang efektifitas minyak kelapa dan minyak zaitun terhadap pencegahan diaper dermatitis pada anak usia 3 - 24 bulan, bahwa jumlah responden yang mengalami diaper dermatitis dengan terapi minyak kelapa lebih sedikit dibanding dengan responden yang mendapatkan terapi minyak zaitun, hal ini hasil menunjukan lebih efektif minyak kelapa daripada minyak zaitun terhadap pencegahan diaper dermatitis pada anak usia $3-24$ bulan di RSUD Tugurejo Semarang. ${ }^{10}$

Coconut oil adalah minyak kelapa murni yang hanya bisa dibuat dengan bahan kelapa segar non-kopra, pengolahan nya pun tidak menggunakan bahan kimia dan tidak menggunakan pemanasan yang tinggi serta tidak dilakukan pemurnian lebih lanjut, karena minyak kelapa murni sangat alami dan sangat stabil jika digunakan dalam beberapa tahun kedepan. ${ }^{4}$ Coconut oil juga mengandung pelembab alamiah dan mengandung asam lemak jenuh rantai sedang yang mudah masuk ke lapisan kulit dan mempertahankan kelenturan serta kekenyalan kulit. Asam laurat dan asam kaprat yang terkandung di dalam coconut oil mampu membunuh virus. Di dalam tubuh, asam laurat diubah menjadi monokaprin, senyawa ini termasuk senyawa monogliserida yang bersifat sebagai antivirus, antibakteri, antibiotik dan antiprotozo. ${ }^{5}$

Minyak kelapa adalah solusi yang aman untuk mencegah kekeringan dan pengelupasan kulit, manfaat minyak kelapa pada kulit adalah sebanding dengan minyak mineral, tidak memiliki efek samping yang merugikan pada kulit. Hal ini minyak kelapa juga membantu dalam mengobati berbagai masalah kulit termasuk psoriasis, dermatitis, eksim dan infeksi kulit lainnya. ${ }^{6}$

\section{PENUTUP}

Hasil penelitian pengaruh pemberian Coconut oil terhadap kejadian ruam popok pada bayi di Posyandu Flamboyan Wilayah Puskesmas Karangjaya Pedes 2017 yang dilakukan sebelum dan sesudah diberikan Coconut oil dapat disimpulkan sebagai berikut :

1. Rata-rata kejadian ruam popok pada bayi di Posyandu Flamboyan Wilayah 
Puskesmas Karangjaya Pedes sebanyak 16 orang bayi diantaranya 8 orang bayi yang mengalami derajat 1 dan 8 orang bayi yang mengalami derajat 2 .

2. Rata-rata karakteristik kondisi derajat ruam popok sebelum dilakukan pemberian Coconut oil dari 16 (100\%) responden, terdapat 8 bayi yan mengalami ruam popok derajat 1 denga besar persentase $50 \%$ dan terdapat 8 bay yang mengalami ruam popok derajat 2 dengan persentase $50 \%$, dengan nilai rata-rata 1,50 .

3. Rata-rata karakteristik kondisi derajat ruam popok setelah dilakukan pemberian Coconut oil dari 16 (100\%) responden, terdapat 7 bayi yang mengalami ruam popok derajat 0 (Tidak ada ruam) dengan besar persentase $43,8 \%$, terdapat 7 bayi yang mengalami ruam popok derajat 1 dengan persentase $43,8 \%$, dan terdapat 2 bayi yang mengalami ruam popok derajat 2 dengan persentase 12,5\%, dengan nilai rata-rata 0,69 . Diantaranya 6 bayi yang mengalami ruam popok derajat 2 menjadi ruam popok derajat 1 , 6 bayi yang mengalami ruam popok derajat 1 menjadi ruam popok derajat 0 , 1 bayi yang mengalami ruam popok derajat 2 menjadi ruam popok derajat 0 , terdapat 2 bayi yang tidak mengalami perubahan diantaranya bayi yang mengalami ruam popok derajat 1 setelah 4 hari pemberian coconut oil tidak mengalami perubahan masih mengalami derajat 1, serta bayi yang mengalami ruam popok derajat 2 setelah 4 hari pemberian coconut oil tidak mengalami perubahan masih mengalami ruam popok derajat 2 , dan terdapat 1 bayi yang mengalami peningkatan/memperparah ruam popok diantaranya bayi yang mengalami ruam popok derajat 1 setelah 4 hari pemberian coconut oil ruam popok bayi mengalami peningkatan menjadi derajat 2.

4. Ada pengaruh pemberian Coconut oil terhadap kejadian ruam popok pada bayi di Posyandu Flamboyan Wilayah Puskesmas Karangjaya Pedes dengan $P$ value $(0,000)$.

\section{)AFTAR PUSTAKA}

a. Kyle, T. dan Carman. S. 2014. Buku Ajar Keperawatan Pediatri. EGC. Jakarta (Sitompul, 2014).

b. Manggiasih, A.V. dan Jaya, Pongki. 2016. Buku Ajar Asuhan Kebidanan Pada Neonatus, Bayi, Balita dan Anak Pra Sekolah. TIM. Jakarta

c. Brian. dan Shilhavy, Marianita. 2012. Virgin Coconut Oil (How it has changed people's lives, and how it can change yours!). Sophia Media. Amerika

d. Purwanto, Budhi. 2013. Herbal dan Keperawatan Komplementer (Teori, Praktik, Hukum dalam Asuhan Keperawatan). Nuha Medika. Yogyakarta

e. Vala, G.S. dan Kapadiya, P.K. 2014. Medicinal Benefits of Coconut Oil, International Journal of Life Sciences Research. District-Bhavnagar (Gujarat), (2) : p.124-126

f. La Ramba, Hardin. Dan Nurbaya, Siti. Kejadian Iritasi Kulit (Ruam Popok) Pada Bayi Usia 0-12 Bulan, journal of Pediatric Nursing. STIKES Nani Hasanuddin Makassar, (2) : p.087-092

g. Merrill, Lisa. 2015. Continuing Nursing Education (CNE) Credit, Prevention, Treatment and Parent Education for Diaper Dermatitis

h. Susanti, F.S. 2013. 132 Jawaban Dokter Untuk Perawatan \& Perkembangan Bayi 0-12 Bulan. Anak Kita. Jakarta

i. Notoatmodjo, Soekidjo. 2012. Metodologi Penelitian Kesehatan. PT. Rineka Cipta. Jakarta 
j. Watti Widya, A. W. dkk. 2013. Efektifitas Minyak Kelapa Dan Minyak Zaitun Terhadap Pencegahan Diaper Dermatitis Pada Anak Usia 3 - 24 Bulan Di RSUD Tugurejo Semarang. 
